\title{
Pulmonary Endothelial Cell ATP Depletion Following Intestinal Ischemia
}

\author{
Todd M. Gerkin, M.D., Theodore H. Welling, B.S., Richard H. Turnage, M.D., Una S. Ryan, Ph.D., \\ Karen S. Guice, M.D., ${ }^{*}$ and Keith T. Oldham, M.D. $\dagger$ \\ Sections of General Surgery and Pediatric Surgery, Department of Surgery, University of Michigan Medical School, Ann Arbor, Michigan 48109; \\ and Divisions of *General and Thoracic Surgery and †Pediatric Surgery, Department of Surgery, \\ Duke University Medical Center, Durham, North Carolina 27710
}

Presented at the Annual Meeting of the Association for Academic Surgery, Colorado Springs, Colorado, November 20-23, 1991

\begin{abstract}
Multiple organ failure (MOF) is known to follow systemic inflammatory mediator activation associated with intestinal ischemia-reperfusion injury. In particular, the pulmonary microvasculature appears to be susceptible to MOF-related injury. This study was designed to evaluate the hypothesis that non-cellular plasma factors associated with intestinal ischemia without reperfusion also mediate pulmonary endothelial cell injury. Male Sprague-Dawley rats had intestinal ischemia induced by microvascular clip occlusion of the superior mesenteric artery for $30,60,90$, or 120 min. Following each period of ischemia, plasma samples were obtained from the portal vein. Time-matched sham-operated animals served as controls. Monolayers of cultured rat pulmonary artery endothelial cells were then incubated with the plasma samples and ATP levels determined using a luciferin-luciferase assay. ${ }^{51} \mathrm{Cr}$ release assay using labeled endothelial cells was performed under identical conditions to assess cytotoxicity. Endothelial cell ATP levels were $1.99 \pm 0.23 \times$ $10^{-11} \mathrm{~mole} / \mu \mathrm{g}$ DNA in sham preparations. After a 4-hr incubation in plasma from the 90 and $120 \mathrm{~min}$ ischemia groups, cellular ATP levels fell significuntly to $1.07 \pm$ $0.23 \times 10^{-11} \mathrm{~mole} / \mu \mathrm{g}$ DNA, respectively $(P<0.005)$. No significant cytotoxic injury resulted from incubation with plasma from the $120 \mathrm{~min}$ group $(1.0 \pm 0.4 \%$ versus $0.8+0.4 \%$ in sham group, $P=N S$ ). All animals survived $24 \mathrm{hr}$ in the sham, 30 , and $60 \mathrm{~min}$ groups. However, survival was 40 and $0 \%$ in the 90 and 120 min groups, respectively $(P<0.001)$. These data are consistent with the hypothesis that intestinal ischemia results in the appearance of non-cellular humoral mediators which cause endothelial cell ATP depletion without cellular death, possibly contributing to the pathogenesis of MOF-related acute lung injury. There is a strong correlation of the in vitro data with in vivo survival. (c) 1992 Academic Press, Inc.
\end{abstract}

\section{INTRODUCTION}

Multiple organ failure is the leading cause of death in surgical and trauma patients in the critical care environ- ment [1]. Multiple organ failure, or MOF, may be defined as a progressive deterioration in the ability of the visceral organs to perform normal physiologic functions. The acute lung injury associated with the MOF syndrome is a subject of particular current interest and great clinical importance [2-4]. The adult respiratory distress syndrome (ARDS) accounts for a substantial portion of the morbidity and mortality associated with multiple organ failure and may account for over 100,000 deaths annually in the United States [5]. ARDS carries an overall mortality of greater than $50 \%$ in the context of MOF syndrome [6,7]. While new therapeutic modalities are being introduced, current interventions are directed at the late consequences of pulmonary dysfunction, as the underlying pathogenic mechanisms of ARDS remain incompletely understood. The pathogenic events which initiate multiple organ failure include many common clinical conditions. Thermal injury $[8,9]$, sepsis [10], hemorrhagic shock [11], trauma [12], acute pancreatitis [2], and ischemia-reperfusion events [3] are all known precipitants of MOF. Each stimulus is apparently unique; however, all are associated with activation of the endogenous inflammatory response. Experimentally, reperfusion of ischemic tissue is associated with injuries to the lungs, liver, and kidneys [3,11]. Ample evidence implicates both cellular and humoral components of the inflammatory response $[13,14]$. These inflammatory mediators may participate in common fundamental events that result in distant organ injury.

An in vivo ARDS-like lung injury has previously been described following intestinal ischemia-reperfusion injury in the rat [3]. The present study was designed to evaluate the hypothesis that non-cellular plasma factors associated with intestinal ischemia without reperfusion mediate pulmonary endothelial cell injury. An in vivo preparation was designed to permit exposure of endothelial cells to plasma constituents in the absence of cellular elements (i.e., neutrophils, monocytes, lymphocytes). Further, the lethality of the intestinal ischemic injury was assessed at both cellular and systemic levels. 


\section{METHODS}

\section{Animal Model}

Pathogen-free male Sprague-Dawley rats $(150-200 \mathrm{~g}$, Charles River Laboratory, Inc., Portage, MI) were used for all experiments. Anesthesia was administered by intramuscular (im) injection of $100 \mathrm{mg} / \mathrm{kg}$ of ketamine hydrochloride (Aveco Co., Inc., Fort Dodge, IA). Midline laparotomy was performed and the superior mesenteric artery (SMA) was occluded by application of a noncrushing microvascular clip. Intestinal ischemia was maintained by SMA occlusion for $30,60,90$, or $120 \mathrm{~min}$. This procedure generated a profound reduction in intestinal blood flow previously confirmed by laser-Doppler [3] and microsphere analysis [15]. In addition, hemodynamic stability was maintained during the experimental time periods [3]. Sham-operated control animals underwent identical preparation except that the SMA clip was not applied (no ischemic injury resulted). A second laparotomy was performed following a second anesthetic (50 $\mathrm{mg} / \mathrm{kg}$ im ketamine hydrochloride) and blood samples were obtained from the portal vein after desired ischemic and sham time intervals; the microvascular clip remained in place while the blood was drawn so that no period of reperfusion was included. Sacrifice was by exsanguination following the portal venous phlebotomy. Samples were drawn into cold heparin-coated plastic syringes and pooled for each experimental group. The pooled blood samples were then centrifuged at $3000 \mathrm{~g} \times$ $15 \mathrm{~min}$ at $3^{\circ} \mathrm{C}$. Plasma from each sample was decanted into cold sterile plastic conicals and held on ice until use.

\section{Endothelial Cell Preparation}

Rat pulmonary artery endothelial cells were provided by U. Ryan (Washington University, St. Louis); the isolation and characterization of these cells has been previously described [16]. Cells were maintained in culture using minimal essential medium of Eagle with Earle's balanced salt solution (Whittaker Bioproducts, Inc., Walkersville, MD) supplemented with $10 \%$ fetal bovine serum, $0.1 \mathrm{~m} M$ nonessential amino acids (GIBCO Laboratories, Inc., Grand Island, NY), $2.0 \mathrm{mM}$ L-glutamine (Irvine Scientific, Santa Ana, CA), $100 \mathrm{U} / \mathrm{ml}$ penicillin $\mathrm{G}, 100 \mu \mathrm{g} / \mathrm{ml}$ streptomycin sulfate, and $0.25 \mu \mathrm{g} / \mathrm{ml}$ fungizone. The cells were grown at $37^{\circ} \mathrm{C}$ in a humidified $5 \%$ $\mathrm{CO}_{2}$ atmosphere. Cells were subcultured by trypsinization when confluent monolayers were obtained.

\section{Cellular ATP Determination}

Endothelial cells were seeded into a 24 -well culture plate in $1 \mathrm{ml} /$ well of culture media. Cells were incubated until near-confluent monolayers were achieved (80-90\% confluency) representing approximately $2 \times 10^{5}$ cells/ well. Each monolayer was then washed twice with Dulbecco's modified Eagle medium (DMEM, GIBCO).

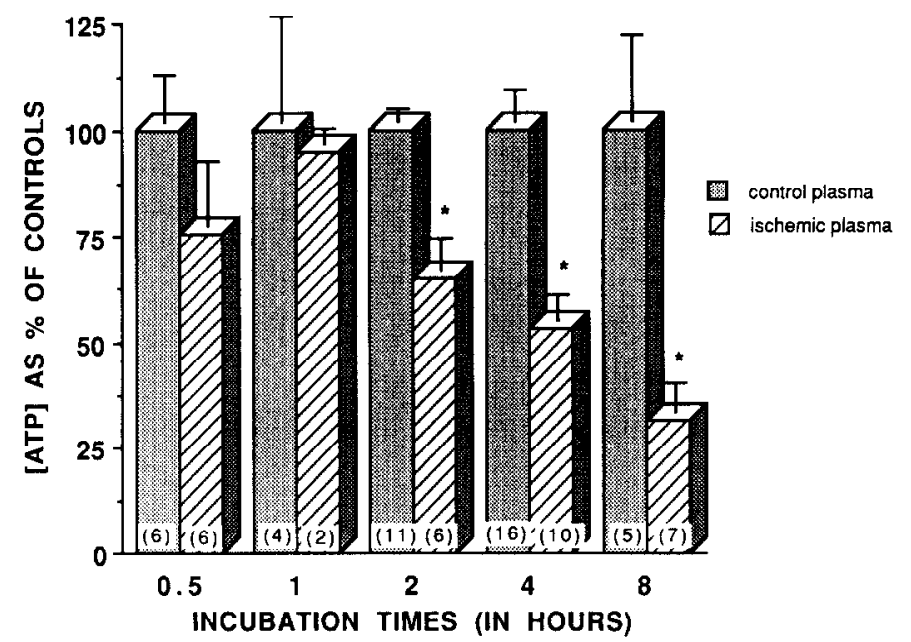

FIG. 1. Time course of endothelial cell ATP depletion after incubation with plasma obtained from uninjured control animals and plasma after $120 \mathrm{~min}$ of ischemia. Sample size indicated in parenthesis. ${ }^{*} P<0.05$ compared to endothelial cells treated with control plasma).

Plasma from each experimental ischemia group, as well as the sham group, was then diluted with DMEM to $25 \%$ (v/v) and $1.0 \mathrm{ml}$ placed onto the endothelial monolayers. The 24-well plate was then incubated at $37^{\circ} \mathrm{C}$ in a humidified $5 \% \mathrm{CO}_{2}$ atmosphere for $4 \mathrm{hr}$. The incubation time of $4 \mathrm{hr}$ was predetermined by incubating endothelial cells with experimental plasma for $30 \mathrm{~min}, 1,2,4$, or $8 \mathrm{hr}$ and measuring cellular ATP as described below. These data are shown in Fig. 1. At the conclusion of the incubation period, the entire 24-well plate was snap frozen in a liquid nitrogen bath and stored at $-70^{\circ} \mathrm{C}$.

At the time of the assay, the 24 -well plate was slowly warmed to the melting point and then held on ice. Each individual well was sonicated for $15 \mathrm{sec}$ to lift and disrupt any intact or adherent endothelial cells (Kontes, Micro Ultrasonic Cell Disrupter, Model ASI). Cellular ATP levels were determined by the method of Stanley and Williams [17] as adapted for use with endothelial cells [18] with modifications as described. Luciferin-luciferase in glycine salt (Sigma Chemical Co., St. Louis, $\mathrm{MO}$ ) was prepared 30 min prior to use by mixing with sterile $\mathrm{H}_{2} \mathrm{O}$ to a final concentration of $4.0 \mathrm{mg} / \mathrm{ml}$. A standard stock solution of $10 \mathrm{mM}$ adenosine 5 'triphosphate (ATP) disodium salt (Sigma) was prepared in phosphate buffer $\left(10 \mathrm{mM} \mathrm{KH} \mathrm{KO}_{4}, 4 \mathrm{mM} \mathrm{MgSO}_{4}, \mathrm{pH}\right.$ 7.75) and stored at $-70^{\circ} \mathrm{C}$. Eight standard curve solutions were prepared by serially diluting this stock solution for an (ATP) range of $10^{-4}$ to $10^{-9} \mathrm{M}$. Using a dry heating block, $1.5-\mathrm{ml}$ aliquots of the phosphate buffer were dispensed into test tubes and preheated to $100^{\circ} \mathrm{C}$. Aliquots of $250 \mu \mathrm{l}$ were taken of standards and samples and added to the boiling phosphate buffer. After vortexing, the solutions were heated for $5 \mathrm{~min}$ at $100^{\circ} \mathrm{C}$ and then placed on ice. In order to eliminate any artifactual enzymatic ATP hydrolysis during the assay, $1.0 \mathrm{ml}$ of 
each sample or standard solution was mixed with $1.5 \mathrm{ml}$ of arsenic buffer $\left(10 \mathrm{mM} \mathrm{Na}_{2} \mathrm{HAsO}_{4}, 4 \mathrm{mM} \mathrm{MgSO}_{4}, \mathrm{pH}\right.$ 7.75). A $500-\mu \mathrm{l}$ aliquot of the samples or standards in arsenic buffer was then transferred to a luminometer cuvette. Luminescence intensity was measured by integration for 10 sec after a 2 -sec delay upon addition of 100 $\mu l$ of the luciferin-luciferase reagent using an LKB-Wallac 1251 Luminometer and 1291 Dispenser (LKB-Wallac, Turku, Finland).

\section{DNA Determination}

Following sampling of the 24-well plate for ATP determination, DNA analysis was carried out using the method of Labarca and Paigen [19] as modified below. Hoechst 33258 reagent (Sigma) was prepared by diluting in phosphate-buffered saline (PBS, $\mathrm{pH}$ 7.4) to a final concentration of $20 \mu \mathrm{g} / \mathrm{ml}$. A standard stock solution of highly polymerized calf thymus DNA sodium salt (Sigma) was prepared by dissolving $1.0 \mathrm{mg}$ DNA in 10.0 $\mathrm{ml}$ PBS. Standard curve solutions were prepared by serially diluting the stock solution to a range of concentrations from 5 to $100 \mu \mathrm{g} / \mathrm{ml}$. The final assay solution consisted of $100 \mu \mathrm{l}$ of standard solution or sample (directly from 24-well plate), $100 \mu \mathrm{l}$ of Hoechst 33258 reagent solution, and $1.8 \mathrm{ml}$ of DNA buffer $\left(50 \mathrm{mM} \mathrm{NaH} \mathrm{PO}_{4}, 50\right.$ $\mathrm{mM} \mathrm{Na} \mathrm{NPO}_{4}, 2.0 \mathrm{M} \mathrm{NaCl}, \mathrm{pH}$ 7.4). After vigorous vortexing, fluorescence was measured at $356 \mathrm{~nm}$ excitation and 458 emission on a Perkin-Elmer LS-5B fluorometer.

\section{Cytotoxicity Assay}

Cytotoxicity was measured using a ${ }^{51} \mathrm{Cr}$-release assay [20]. Endothelial cells were seeded into a 24-well culture plate. Each well received $2 \mu \mathrm{Ci}$ of $\mathrm{Na}^{51} \mathrm{CrO}_{4}$ (New England Nuclear, Boston, MA). The plate was incubated for $24 \mathrm{hr}$ until monolayers reached near confluency (approximately $2 \times 10^{5}$ cell/well). Immediately prior to use, monolayers were washed twice with DMEM to remove unincorporated radioactivity. Cells were then incubated in 25\% plasma as described for ATP determinations. Following a 4-hr incubation period, culture media was removed from each well and centrifuged at $3000 \mathrm{~g} \times 5$ min. The supernatants $(0.5 \mathrm{ml})$ were aspirated and analyzed on a gamma counter (Auto-Gamma 5000, Packard Instrument Co., Downers Grove, IL). Spontaneous release was measured in wells receiving $0.2 \%$ Triton $\mathrm{X}-100$. Spontaneous release measured less than $10 \%$ in all experiments. Cytotoxicity was then calculated using the following formula:

$\%$ Cytotoxicity $=\left[\frac{\mathrm{CPM}_{\text {experimental }}-\mathrm{CPM}_{\text {control }}}{\mathrm{CPM}_{\text {maximal }}-\mathrm{CPM}_{\text {control }}}\right] \times 100 \%$

\section{Postoperative Survival Analysis}

Animals were prepared for operation as described above. Laparotomy was carried out as before with appli- cation of a microvascular clip to the SMA. Intestinal ischemia was maintained for periods of $30,60,90$, or 120 min, and sham-operated control animals again underwent an identical preparation except that the SMA clip was not applied. At the conclusion of these time intervals, a second laparotomy was performed following a second anesthetic $(50 \mathrm{mg} / \mathrm{kg}$ im ketamine hydrochloride) and the SMA clip removed. All animals then had the midline incision closed with a single-layer running suture closure and were placed in separate cages with adequate food and water to recover from ketamine anesthesia. Animals were assessed for survival and classified as either alive or dead based upon evidence of respiratory effort and ongoing cardiovascular activity at 12- and 24$\mathrm{hr}$ time periods postoperatively. All survivors at the conclusion of the 24-hr time period assessment were sacrificed using an overdose of intravenous anesthesia (ketamine).

\section{Statistical Methods}

All data are expressed as the mean plus or minus the standard error of the mean (SEM). Statistical analysis was performed using analysis of variance (ANOVA) and a post hoc comparison among groups with Fisher's protected least squares difference test. Significance was assigned when the $F$ test for multicomparison was significant and $P<0.05$ was achieved.

\section{RESULTS}

\section{Time Course of Cellular ATP Depletion (Fig. 1)}

Endothelial cell ATP levels were measured following incubation for $30 \mathrm{~min}, 1,2,4$, and $8 \mathrm{hr}$ with plasma obtained from sham operated control animals or animals with 120 minutes of intestinal ischemia alone. As shown in Fig. 1, endothelial cells incubated with ischemic plasma show a progressive decrease in the content of ATP compared to controls. ATP content dropped from $95.2 \%$ of control levels at $1 \mathrm{hr}$ of incubation to $31.4 \%$ of control values after $8 \mathrm{hr}$ of incubation. The incubation time of $4 \mathrm{hr}$ was selected for the experiments that follow because it represents a significant injury $(50 \%$ decrease in the amount of measured ATP), and because the absolute ATP quantities remained relatively stable at this time.

\section{Cellular ATP Depletion by Ischemic Plasma}

Endothelial cell ATP levels were measured following a 4-hr incubation period with plasma obtained from the portal vein following various periods of intestinal ischemia ("ischemic plasma"). As shown in Fig. 2, endothelial cells exposed to ischemic plasma from animals subjected to longer periods of ischemia demonstrated a significant decrease in cellular ATP levels. Pulmonary endothelial cells incubated in plasma from sham-oper- 


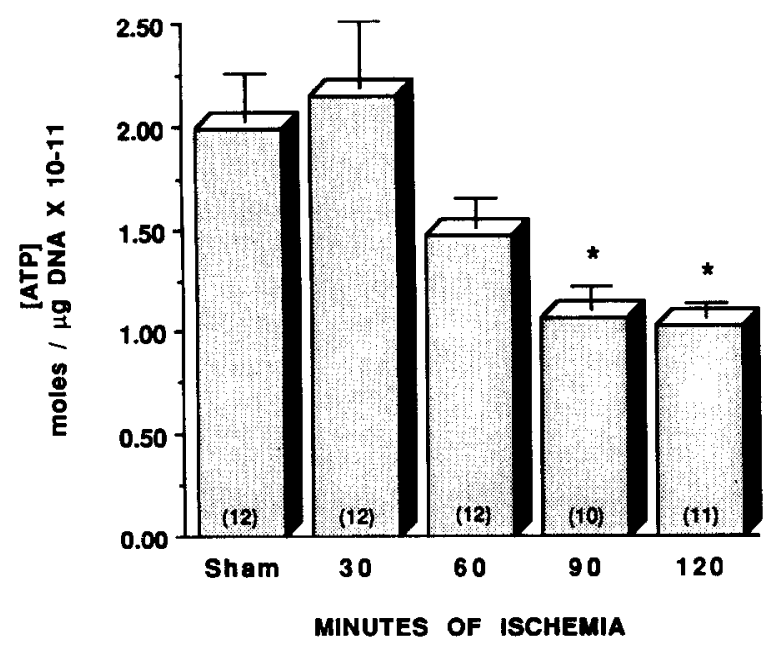

FIG. 2. Endothelial cell ATP levels following $4 \mathrm{hr}$ incubations in plasma obtained after indicated period of intestinal ischemia. Data are pooled from three experiments with sample size indicated in parenthesis. Time points on the $x$-axis represent minutes of intestinal ischemia prior to portal venous phlebotomy. $\left({ }^{*} P<0.005\right.$ versus sham control).

ated animals had a stable ATP level of $1.99 \pm 0.23 \times$ $10^{-11} \mathrm{~mole} / \mu \mathrm{g}$ DNA. Incubation in plasma from animals sustaining $30 \mathrm{~min}$ of intestinal ischemia resulted in no significant change in ATP $\left(2.15 \pm 0.32 \times 10^{-11} \mathrm{~mole} / \mu \mathrm{g}\right.$ DNA, $P=$ NS). However, upon incubation with ischemic plasma in the 60-min group, cellular ATP concentrations began to decrease, although not significantly $\left(1.46 \pm 0.14 \times 10^{-11} \mathrm{~mole} / \mu \mathrm{g}\right.$ DNA, $\left.P=0.54\right)$. With exposure to plasma obtained after 90 and 120 min of intestinal ischemia, endothelial cell ATP levels fell significantly to $1.07 \pm 0.11 \times 10^{-11} \mathrm{~mole} / \mu \mathrm{g}$ DNA and $1.02 \pm$ $0.07 \times 10^{-11} \mathrm{~mole} / \mu \mathrm{g}$ DNA $(P<0.005)$, respectively.

\section{Cytotoxic Injury to Endothelial Cells}

The ${ }^{51} \mathrm{Cr}$-release assay is a reliable and quantitative method of analyzing cytotoxic injury to endothelial cells that results in cell membrane disruption. In view of the observation that endothelial cell ATP levels were significantly diminished by exposure to ischemic plasmas, the question of whether this represented a cytotoxic event was assessed. As plasma from the most severe intestinal injury group ( $120 \mathrm{~min}$ of ischemia) resulted in the greatest depletion of cellular ATP, the ${ }^{51} \mathrm{Cr}$-release assay was used to compare cells incubated in control media, sham plasma, and 120 min ischemic plasma. As shown in Fig. 3 , no significant cytotoxicity resulted from a 4-hr incubation under the previously described conditions. The control group measured $0.0 \pm 0.1 \%$, the sham group measured $0.8 \pm 0.4 \%$, and the $120 \mathrm{~min}$ group measured $1.0 \pm 0.4 \%) P=$ NS versus sham). Hydrogen peroxide exposure at a concentration of $500 \mathrm{nmol} / \mathrm{ml}$ served as an internal positive control and consistently produced a cytotoxic injury killing $85.0 \pm 2.5 \%$ of the endothelial cells.

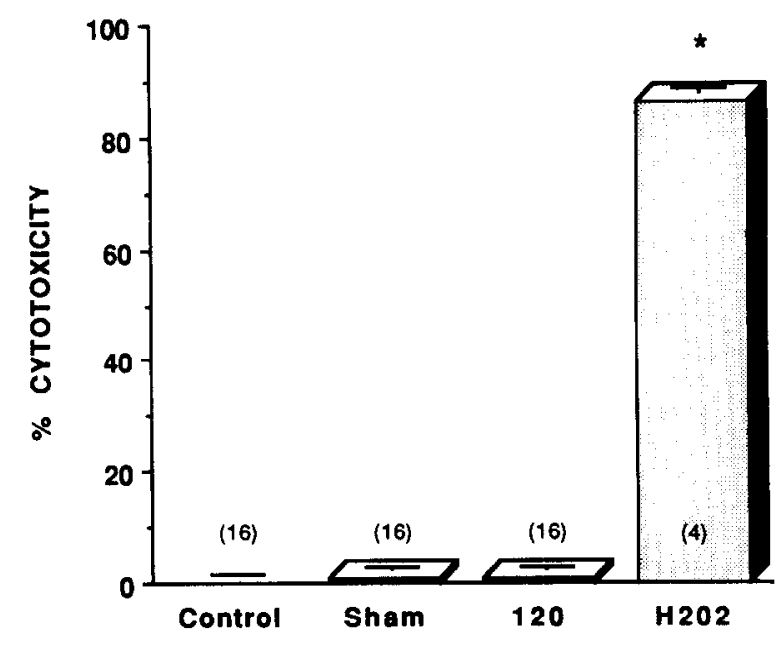

FIG. 3. Assessment of cytotoxicity for endothelial cells incubated for $4 \mathrm{hr}$ in normal growth media (control), plasma from sham-operated animals (sham), or plasma from animals sustaining $120 \mathrm{~min}$ of intestinal ischemia (120). Sample size indicated in parentheses. $\mathrm{H}_{2} \mathrm{O}_{2}$ injury served as an internal positive control. $\left({ }^{*} P<0.001\right.$ versus sham).

\section{Postoperative Survival Following Intestinal Ischemia}

Animal survival was measured at 12 and $24 \mathrm{hr}$ after the intestinal ischemic event and provides a potentially relevant clinical observation. As shown in Fig. 4, animals in the sham-operated, 30 , and 60 min groups had a $100 \%$ survival rate $24 \mathrm{hr}$ after operation. However, animals sustaining 90 min of intestinal ischemia had a survival rate of $60 \%$ at $12 \mathrm{hr}(P<0.01$ versus sham $)$ and only $40 \%$ by $24 \mathrm{hr}$ post-op ( $P<0.001$ versus sham). Thus, 90 min of intestinal ischemia appears to approximate the LD50 for this type of injury. After sustaining 120 min of intestinal ischemia, no animals survived the

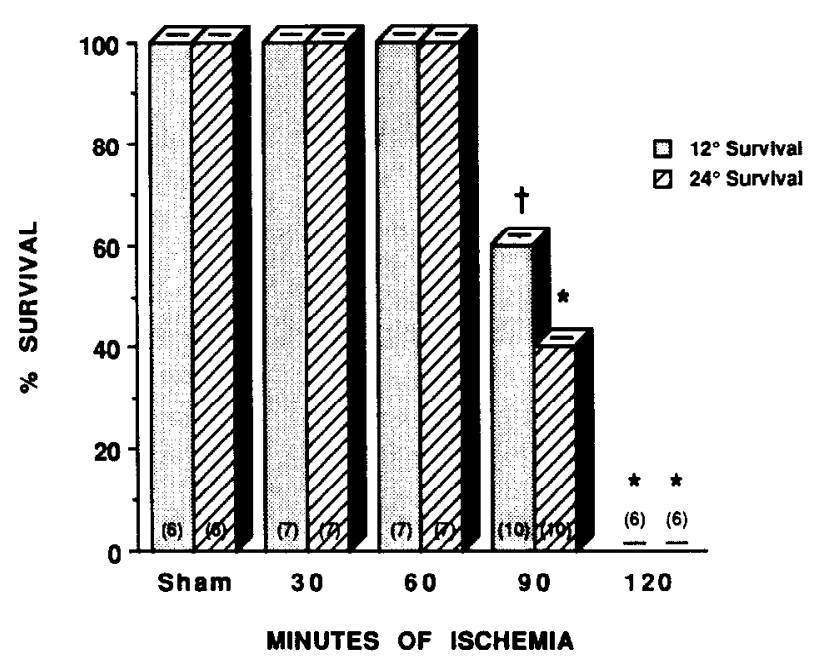

FIG. 4. Survival rates in animals subjected to intestinal ischemia measured at 12 and $24 \mathrm{hr}$ postoperatively. Sample size indicated in parentheses. Time points on the $x$-axis represent minutes of intestinal ischemic injury sustained. $\left(+P<0.01\right.$ versus sham; ${ }^{*} P<0.001$ versus sham). 
12 or $24 \mathrm{hr}$ postoperative intervals $(P<0.001$ versus sham for both 12 and $24 \mathrm{hr}$ ).

\section{DISCUSSION}

Multiple organ failure is characterized by progressive deterioration in the ability of visceral organs to perform normal physiologic functions. Although the pathogenesis of MOF is incompletely understood, systemic inflam matory mediator activation appears to play a major role in this process. Many cellular and humoral mediators have been implicated. Among these, neutrophils and their products [20], cytokines [21, 22], and endotoxin [23] are potentially relevant in this particular model. In particular, the proinflammatory cytokines IL-1 and TNF set in motion a cascade of events in the endothelial microenvironment leading to cytokine synthesis, leukocyte adhesion and transmigration, enhanced basement membrane permeability, and increased capillary leak [24]. In addition, the endothelial cell is rendered more susceptible to neutrophil-mediated killing [25]. Caty previously demonstrated elevation of TNF levels in plasma following intestinal ischemia-reperfusion injury; however, this elevation required reperfusion of the ischemic segment [26] and may not explain cellular ATP depletion seen with ischemia alone.

Vascular endothelium appears to be a critical early target in the pathogenesis of distant organ injury associated with activation of the inflammatory cascade. Intact endothelial cell metabolic and functional activities are required to maintain the integrity of the vascular compartment. Inflammation results in accumulation of leukocytes, platelets, plasma proteins, and interstitial fluid at the site of the injury. Previously, the endothelial cell was thought to function as a passive barrier between cellular and plasma constituents of the blood and the extravascular tissues. Loss of integrity of the endothelial monolayer was attributed to direct endothelial cell injury with subsequent breach of the basement membrane and infiltration of inflammatory cells, and tissue edema formation. Evidence continues to accumulate, however, that the vascular endothelial cell is an active participant in the processes of inflammation and tissue injury [27]. Local and systemic regulation of the circulation, control of anticoagulant and thrombotic processes, leukocyte adhesion and transmigration mechanisms, mediator synthesis, and regulation of basement membrane integrity appear to be among the events for which the endothelial cell has a significant role $[24,28]$. Therapeutic interventions that interrupt these processes are likely to be helpful in the treatment of the MOF syndrome.

The present study utilizes a model designed to evaluate the effects of noncellular plasma factors on the pulmonary endothelial cell. Ample evidence supports the concept that the pulmonary microvasculature is a primary and particularly vulnerable site for inflammatory injury initiated by a variety of clinical conditions and mediated by cytokines $[6,21]$, neutrophils $[29,30]$, proteases [31], and toxic oxygen metabolites [32].

These data demonstrate that non-cellular plasma factors associated with intestinal ischemia result in depletion of pulmonary endothelial cell energy stores in vilru. Despite a decrease of nearly $50 \%$ in cellular ATP levels under these conditions, no significant cytotoxic injury occurs. A dose-response pattern does exist with correlation of the duration of intestinal ischemia and the subsequent fall in pulmonary endothelial cell ATP levels. A similar dose-response trend is noted when animal survival is examined, with the LD50 being approximately $90 \mathrm{~min}$ of intestinal ischemia. The in vivo and in vitro findings are consistent with one another.

Protein synthesis, mRNA transcription, granule exocytosis, and presentation of cell surface adhesion molecules are all energy-dependent processes requiring ATP consumption to proceed. Clearly, alteration of essential cellular events by ATP depletion represents a threat to the viability of the cell. The endothelial cell ATP depletion in this model appears to depend upon the duration of the intestinal ischemic injury, suggesting a relationship between the degree of ischemic bowel injury and subsequent ATP depletion. The time course of ATP depletion correlates closely with the known temporal sequence for onset of peak procoagulant activity [28], ELAM-1 and ICAM-1 expression [33, 34], and cytokine synthesis and release [24].

In summary, this study makes use of both in vivo and in vitro models to investigate the pathogenesis of acute pulmonary endothelial cell injury following intestinal ischemia. Plasma factors, independent of the neutrophil, resulted in endothelial cell ATP depletion without cell death. Depletion of vascular endothelial cell energy stores may be an early, possibly fundamental event in the endothelial cell during the inflammatory injury which is associated with the multiple organ failure syndrome.

\section{REFERENCES}

1. Goris, R. J. A., teBoekhorst, T. P. A., Nuytinck, J. K. S., and Gimbrere, J. S. F. Multiple-organ failure-generalized autodestructive inflammation? Arch. Surg. 120: 1109, 1985.

2. Guice, K. S., Oldham, K. T., Caty, M. G., Johnson, K. J., and Ward, P. A. Neutrophil dependent, oxygen-radical mediated lung injury associated with acute pancreatitis. Ann. Surg. 210: $740,1989$.

3. Schmeling, D. J., Caty, M. G., Oldham, K. T., Guice, K. S., and Hinshaw, D. B. Evidence for neutrophil-related acute lung injury after intestinal ischemia-reperfusion. Surgery 106: 195, 1989.

4. Abdalla, E. K., Caty, M. G., Guice, K. S., Hinshaw, D. B., and Oldham, K. T. Arterial levels of oxidized glutathione (GSSG) reflect oxidant stress in vivo. J. Surg. Res. 48: 291, 1990.

5. National Heart and Lung Institutes. Respiratory Diseases: Task Force Report on Problems, Research Approaches, Needs. Washington DC, U.S. Government Printing Office, Pp. 167-180, 1972. DHEW Pub. NIH 74-432. 
6. Demling, R. H. Current concepts on the adult respiratory distress syndrome. Circ. Shock 30: 297, 1990.

7. Andreadis, N., and Petty, T. L. Adult respiratory distress syndrome: problems and progress. Am. Rev. Respir. Dis. 132: 1344, 1984.

8. Oldham, K. T., Guice, K. S., Till, G. O., and Ward, P. A. Activation of complement by hydroxyl radical in thermal injury. Surgery 104: 272, 1988.

9. Till, G. O., Beauchamp, C., Menapace, D., Tourtellotte, W., Kunkel, R., Johnson, K. J., and Ward, P. A. Oxygen radical dependent lung damage following thermal injury of rat skin. $J$. Trauma 23: 269, 1983.

10. Bell, R. C., Coalson, J. J., Smith, J. D., and Johanson, W. G. Multiple organ system failure and infection in adult respiratory distress syndrome. Ann. Int. Med. 99: 293, 1983.

11. Vedder, N. B., Fouty, B. W., Winn, R. K., Harlan, J. M., and Rice, C. L. Role of neutrophils in generalized reperfusion injury associated with resuscitation from shock. Surgery 106: 509, 1989.

12. Rivkind, A. I., Siegal, J. H., Guadalupi, P., and Littleton, M. Sequential patterns of eicosanoid, platelet, and neutrophil interactions in the evolution of the fulminant post-traumatic adult respiratory distress syndrome. Ann. Surg. 210: 355, 1989.

13. Hernandez, L. A., Grisham, M. B., Twohig, B., Arfors, K. E., Harlan, J. M., and Granger, D. N. Role of neutrophils in ischemia-reperfusion-induced microvascular injury. Am. J. Physiol. 253: H699, 1987.

14. Lucchesi, B. R. Neutrophil-derived oxygen radicals in myocardial reperfusion injury. In G. B. Zelenock (Ed.), Clinical Ischemic Syndromes: Mechanisms and Consequences of Tissue Injury. St. Louis: Mosby, 1989.

15. Turnage, R. H., Abdalla, E. K., Gerkin, T. M., Imlay, M., Gallagher, K., Guice, K. S., and Oldham, K. T. Regional blood flow after intestinal ischemia-reperfusion injury. Circ. Shock 34: 64, 1991. [Abstract]

16. Ryan, U. S., Clements, E., Habliston, D., and Ryan, J. W. Isolation and culture of pulmonary artery endothelial cells. Tissue Cell 10: 535, 1978.

17. Stanley, P. E., and Williams, S. G.: Use of the liquid scintillation spectrometer for determining adenosine triphosphate by the luciferase enzyme. Anal. Biochem. 19: 281, 1969.

18. Hinshaw, D. B., Armstrong, B. C., Burger, J. M., Beals, T. F., and Hyslop, P. A. ATP and microfilaments in cellular oxidant injury. Am. J. Pathol. 132: 479, 1988.

19. Labarca, C., and Paigen, K. A simple, rapid and sensitive DNA assay procedure. Anal. Biochem. 102: 344, 1980.

20. Varani, J., Fligiel, S. E. G., Till, G. O., Kunkel, R. G., Ryan, U. S., and Ward, P. A. Pulmonary endothelial cell killing by human neutrophils - possible involvement of hydroxyl radical. Lab. Invest. 53: $656,1985$.
21. Colletti, L. M., Burtch, G. D., Remick, D. G., Kunkel, S. L., Strieter, R. M., Guice, K. S., Oldham, K. T., and Campbell, D. A. The production of tumor necrosis factor alpha and the development of a pulmonary capillary injury following hepatic ischemia/ reperfusion. Transplantation 49: 268, 1990.

22. Welbourn, R., Goldman, G., Kobzik, L., Paterson, I., Shepro, D., and Hechtman, H. B. Interleukin-2 induces early multisystem organ edema mediated by neutrophils. Ann. Surg. 214: 181, 1991.

23. Mayoral, J. L., and Dunn, D. L. Cross-reactive murine monoclonal antibodies directed against the core/lipid A region of endotoxin inhibit production of tumor necrosis factor. J. Surg. Res. 49: $287,1990$.

24. Pober, J. S., and Cotran, R. S. The role of endothelial cells in inflammation. Transplantation 50: 537, 1990.

25. Varani, J., Bendelow, M. J., Sealey, D. E., Kunkel, S. L., Gannon, D. E., Ryan, U. S., and Ward, P. A. Tumor necrosis factor enhances susceptibility of vascular endothelial cells to neutrophil-mediated killing. Lab. Invest. 59: 292, 1988.

26. Caty, M. G., Guice, K. S., Oldham, K. T., Remick, D. G., and Kunkel, S. L. Evidence for tumor necrosis factor-induced pulmonary microvascular injury after intestinal ischemia-reperfusion injury. Ann. Surg. 212: 694, 1990.

27. Osborn, L. Leukocyte adhesion to endothelium in inflammation. Cell 62: 3, 1990.

28. Bevilacqua, M. P., Pober, J. S., Wheeler, M. E., Cotran, R. S., and Gimbrone, M. A. Interleukin-1 activation of vascular endothelium: Effects on procoagulant activity and leukocyte adhesion. Am. J. Pathol. 121: 393, 1985.

29. Weiss, S. J. Tissue destruction by neutrophils. N. Engl. J. Med. 320: 365, 1989.

30. Jutila, M. A., Berg, E. L., Kishimoto, T. K., Picker, L. J., Bargatze, R. F., Bishop, D. K., Orosz, C. G., Wu, N. W., and Butcher, E. C. Inflammation-induced endothelial cell adhesion to lymphocytes, neutrophils, and monocytes: Role of homing receptors and other adhesion molecules. Transplantation 48: 727, 1989.

31. Schraufstatter, I. U., Revak, S. D., and Cochrane, C. G. Proteases and oxidants in experimental pulmonary inflammatory injury. J. Clin. Invest. 73: 1175, 1984.

32. Weiss, S. J. Oxygen, ischemia, and inflammation. Acta Physiol. Scand. Suppl. 548: 9, 1986.

33. Bevilacqua, M. P., and Gimbrone, M. A. Inducible endothelial functions in inflanmation and coagulation. Semin. Thromb. Ilemostasis 13: 425, 1987.

34. Smith, C. W., Rothlein, R., Hughes, B. J., Mariscalo, M. M., Rudloff, H. E., Schmalstieg, F. C., and Anderson, D. C. Recognition of an endothelial cell determinant for CD18-dependent human neutrophil adherence and transendothelial migration. $J$. Clin. Invest. 82: 1746, 1988. 